\title{
MODELS OF ENTREPRENURSHIP DEVELOPMENT IN RURAL TOURISM DESTINATIONS IN VOJVODINA ${ }^{1}$
}

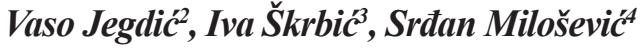

\begin{abstract}
Summary
The subject of the research in this paper is the development and the application of entrepreneurship in rural tourism destinations. The aim of the paper is to identify key forms of rural entrepreneurship tourism in Vojvodina. General analytic-synthetic method of research was applied, spanning from the bibliographic-speculative to empirical approach.

It has been determined that messuages, villages as tourist products, ethno-houses, and rural households that provide services of accommodation and food, eco-active tourism, tourism offer of food and drinks produced in the system of organic production, as well as traditional rural events, can be the basis of rural tourism product in Vojvodina. The development of rural tourism should be based on effective investment in the tourism offer through entrepreneurial projects that are in accordance with modern trends of demand. Investment into tourism offer in rural tourism destinations would influence the growth of income made from rural tourism, and therefore, the economic development of those areas.
\end{abstract}

Key words: rural tourism, rural destination, entrepreneurship in rural tourism, Vojvodina.

JEL: Q01, 018.

\section{Introduction}

Rural tourism is most frequently organized as a family business in local community. That is the source of its strength needed to initiate self-employment in rural environments, as

1 The paper is a part of the research on the project „Models of entrepreneurship development in sustainable tourism of Vojvodina“", No. 114-451-2487/2016-03, financed by the Provincial Secretariat for Science and Technological development AP Vojvodina, for the period 2016-2019.

2 Vaso Jegdić Ph.D., Associate Professor, University of Educons, Faculty of Sport and Tourism, Radnička Street no. 30a, 21000 Novi Sad, Serbia, Phone +381 635506 38, E-mail: vaso.jegdic@tims.edu.rs

3 Iva Škrbić Ph.D., Assistant Professor, University of Educons, Faculty of Sport and Tourism, Radnička Street no. 30a, 21000 Novi Sad, Serbia, Phone +381 642014 738, E-mail: iva@tims.edu.rs

4 Srđan Milošević Ph.D., Assistant Professor, University of Educons, Faculty of Sport and Tourism, Radnička Street no. 30a, 21000 Novi Sad, Serbia, Phone +381 641800431 , E-mail: srdjan.milosevic@tims.edu.rs 
this is a work intense activity. Family organization of labor in rural tourism and a relatively small volume of work enables local tourism to offer what is the key condition in experience economy, which is an authentic experience based on personal contact of rural hosts with tourists, as well as tourists with natural and social environment. If we accept the definition that rural tourism includes all those activities that take place in rural areas, which are based on specificities of rural lifestyle, and which are directed at its preservation, as well as which develop comparative advantages of rural communities, then it is clear that this form of tourism includes diverse activities. Therefore, we can use the term agritourism or tourism that takes place in a countryside household, gastronomic, educational, culturally-historic, adventurous, sports-recreational, ecological, hunting, fisheries rural tourism. It is important to keep in mind that rural tourism must be developed in accordance with the principles of sustainability in its broadest meaning. Sustainability of rural tourism is most broadly defined through: preservation of local culture and identity of local community, preservation of the countryside and natural environment, preservation and sustainable development of rural economy, emphasizing the importance of the support of local, regional and national authorities, but also the balance between tourism activities in a rural area and other activities (Krajnović et al., 2011; Rikalović et al., 2012).

Rural tourism can be seen as one of the mechanisms of reproducing rural economy and rural way of life (Čikić et al., 2015). In defining the term rural tourism, some authors start from the dilemma whether rural tourism or tourism in rural areas should be used as the term, thus wondering if rural tourism is something completely specific or whether it is only tourism taking place in rural space in a specific context. Author Marina Noveli (2005) points to ruralness as an important macro field, within which, specific macro niches are separated (e.g. family farms, festivals and events, trades and folk art, gastronomic offer). Rural tourism is the most encompassing term including all forms of tourism in rural areas (see for example: Lane 1994; Page, Getz 1997; Butler 1998; Garrod et al. 2006; Sharpley, Jepson 2011; Silva, Leal 2015).

Saxena et al. introduce a notion of "integrated rural tourism" - IRT as "tourism explicitly tied to economic, social, cultural, natural and human structure of the location in which it takes place" (Saxena et al., 2007: 3). Basically, the importance of territorial identity and strategic commodification of resources and location is emphasized, as well as the significance of non-local forces in starting local activities (Petrou et al. 2007). The goal of rural tourism management is to achieve sustainable development of rural areas, while respecting their specificities, preserving and affirming the authentic regional and cultural values, as well as the quality of natural environment (Škrbić et al., 2015). In essence, rural tourism is based on the concept of sustainable development of local communities. The idea is to encourage village communities to include new sources of income as additional and not as replacement for the existing activities by developing tourism (McAreavey, McDonagh, 2010).

Although there are numerous rural tourism research studies, there is no universal definition of this term in scientific literature. A suitable definition of rural tourism was formulated by "Trav Info India": "Rural tourism is "any form of tourism that showcases the rural life, art, culture and heritage at rural locations, thereby benefiting the local community economically 
and socially, as well as enabling interaction between the tourists and the local community for a more enriching tourism experience." (www.travinfoindia.com). Rural tourism is one of the alternative development options of rural environments (Fesenmaier et al., 1995) and it leads to the development of rural areas and a better territorial balance in economic and social sense by diversifying activities (Shtaltovna, 2007). It has an influence on economic revitalization, but also on preserving local culture and resources (Rural Sociological Society and the National Coalition for Rural Entrepreneurship, 2006), meaning it influences the raising of confidence of local population (Andrić et al., 2010). Direct influence of local tourism can be seen in increased production and ensuring a safe placement of agricultural products, increased employment of local community and growth of their wages, increased birthrate, while indirect influence of tourism can be seen through the development of other accompanying activities, such as transport infrastructure and cultural development of the community (Đuričić, 2011; Gannon, 1994; Kieselbach, Long, 1990).

\section{Rural space as a system}

The concept of rural spaces is not precisely defined, so this term includes natural areas, rural environment, small settlements and villages, isolated farms with agriculture and forestry as main economic sectors and other (Demonja, Baćac, 2012). Research studies show that rural spaces have high adaptive capacities, meaning that they are "resilient" to external and internal changes. Those changes are partially a result of general global changes, partially of policies, particularly agrarian ones in certain countries, but there are also other driving forces: ecological and sectoral that influence rural areas (Heijman et al., 2007). A more acceptable definition of rural spaces is:

- economically integrated rural spaces, in the proximity of urban centers, with oriented agricultural production that are suitable for progress and changes;

- intermediate rural spaces, as transitional zones with multi-crop production in countryside households; and

- remote rural spaces, with emphasized abandonment of rural areas (Todorović, Štetić, 2009; Bogdanov, 2007).

Rural spaces are structurally very complex systems that consist of several different components. So, Schouten and associates (2009) identified four rural subsystems as the key to understanding how rural spaces function, which are: economic, social, ambience, and public management. Many authors state that rural spaces surpass the four listed components, and they also add cultural component as well as infrastructure. So, the whole matrix of local rural space as a system could consist of six components - specific subsystems (Graph 1.): 
Graph. 1. Subsystems in local rural space as a system and tourism

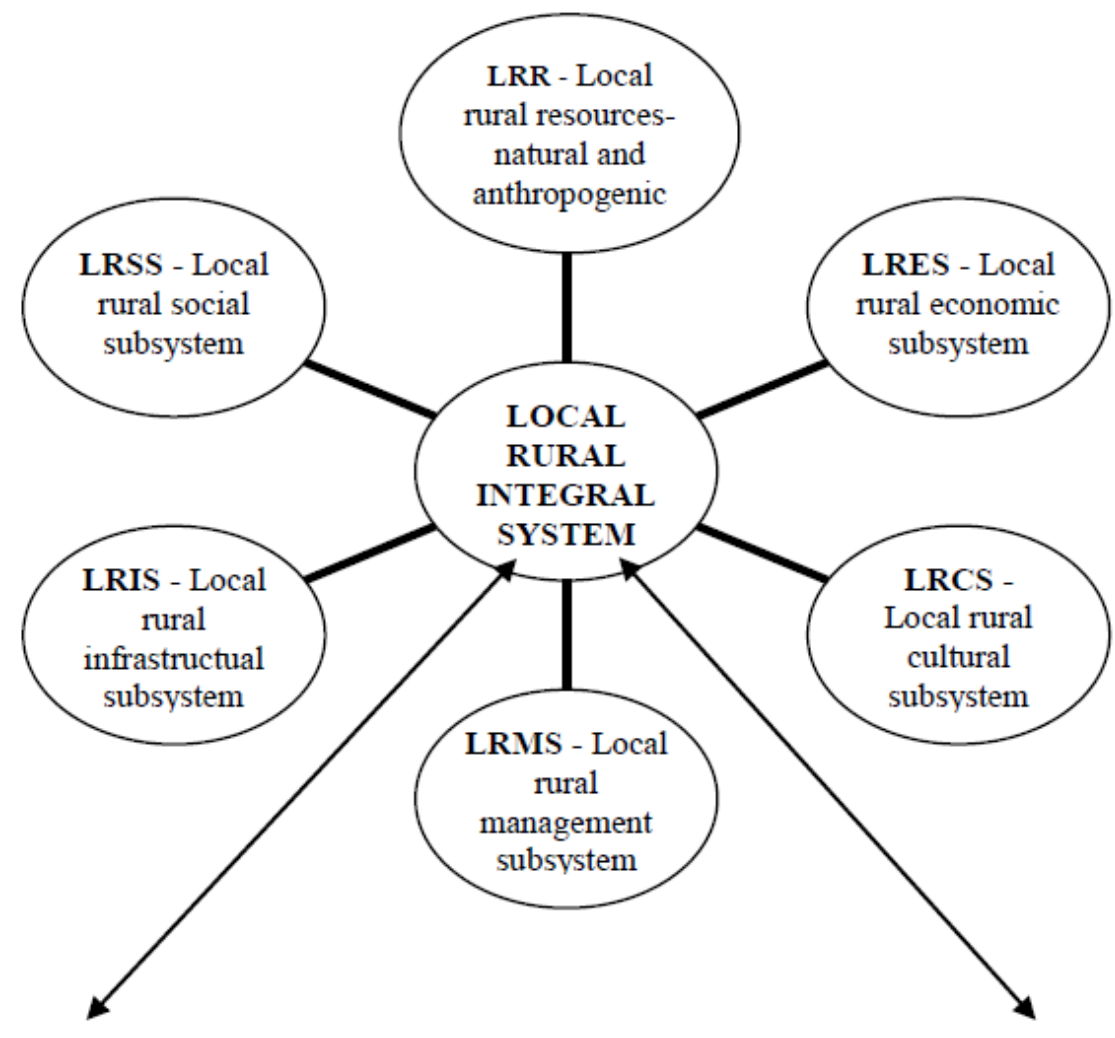

Integral rural tourism management (IRTM)

Source: Vidić, 2012.

Every local rural community, regardless of the geographical area, differs based on the characteristics of their components - subsystems (Vidić, 2012):

- Inimitable local rural resources - LRR: natural and anthropogenic - protected and unprotected

- Specific local rural social subsystems - LRSS: demographic and social characteristics - education, health, employment, using free time, safety, degree of human development

- Different local rural economic subsystems - LRES: diversified agriculture, multifunctional - in certain places, developed or undeveloped, developing

- $\quad$ Authentic local rural cultural subsystems - LRCS: material and spiritual wealth traditional and contemporary

- Different levels of development of local rural infrastructural subsystems - LRIS: highways, water supply, sewage, energetics, phone wiring, inclusion into information systems 
- Centralized or decentralized concept of functioning of local rural management subsystem - LRMS.

Rural tourism functionally integrates all subsystems in local rural space (Graph 1.). Local rural resources are the foundation of rural tourist product, or, local rural tourism. Local rural resources represent a potential for tourism, which can be transformed into rural touristic attractions and can be thematically profiled into extremely diversified rural tourism in rural space (Lane, 1994 and 1999). Lane emphasizes rural resources as the most significant element of the rural tourism system. Some authors address rural resources as "rural capital" (Garrod et al., 2006). Local government in local rural communities, particularly local authorities, can encourage and focus local development and "create, strengthen or stabilize activities by using resources of an area in the best way possible", as it is pointed out by Gref(1994).

\section{Methodology and data sources}

The subject of this research is the development and the application of entrepreneurship in rural tourism destinations in Vojvodina. The research employs analytic-synthetic, bibliographic-speculative and empirical methods. The research was realized in the form of a transversal study of empirical character. General analytical-synthetic method of research is used in the paper, spanning from the bibliographic-speculative to empirical approach, with the application of document content analysis technique. As data sources, required for analysis, records of local tourism organizations and the Tourist Organization of Vojvodina (TOV) were used, available internet sites relevant for target field, official reports of rural organizations and their associations, as well as bibliography. Primary data were collected based on observations in the field and through interviews of owners/managers, who developed various tourism concepts based on entrepreneurship programs in rural communities: messuages, ethno-houses, countryside households and workshops, souvenir and old trades shop, and an offer of organically produced food.The research results indicate possible guidelines and models for further development of entrepreneurship in rural tourism destinations in Vojvodina.

\section{The conditions for the development of rural destinations in Vojvodina}

According to OECD (1994) categorization, around 90\% of Vojvodina's territory is rural area. To be more precise, out of 45 local communities in total, only five are located in the areas that are not considered rural, and those are: Novi Sad, Sremski Karlovci, Stara Pazova, Temerin and Pančevo, while the remaining 40 are categorized as rural areas. The most represented are economically integrated rural areas, with intensive agrarian production, and then intermediate rural areas as transitional zones with multi-crop production in countryside farms, and remote rural areas, with remains of authentic steppe ambiance, which frequently transition from the zone of rare population density into empty spaces under some type of protection regiments. Currently, 6.4\% of Vojvodina's territory is under protection (Puzović, Panjković, 2015), with significant increase tendency sparked by EU demand that Serbia has $10 \%$ of its territory under protection until the moment of joining the EU. 
The essence of every tourist destination is comprised of three groups of elements:

- Attractions and attributes that attract tourists or enrich the content of their stay

- $\quad$ Services of accommodation and food for guests, and

- Activities practiced by the guests, meaning conveniences for practicing those activities (Jegdić, 2010).

The ideal combination is to achieve physical and economic balance of these elements participating in forming an integral tourist product. In the initial structuring of each destination and its positioning in the market, the issue of connecting and / or harmonizing the contents and functions is raised, taking into consideration the demands of the visitors, as well as possibilities provided by a specific destination from the standpoint of its sustainability. Thereby, in rural areas economic, socio-cultural, and ecological sustainability is equally taken into consideration (Jegdić, 2011).

The model of rural destination in Vojvodina must be based on creating wider regional destinations that would include one or more protected areas and surrounding rural areas - eco-rural destinations, with emphasis placed on recreational, cultural, education and other contents compatible with formation of destination chain value, i.e. tourist product - eco-tourism product. Tourist destination Gornje Podunavlje, for example, spans across 152.800 ha, while its protected section, Special Nature Reserve (SNR) "Gornje Podunavlje", includes 19.648 ha, which makes incomplete $13 \%$ of the total total surface of the destination. In such wholesome areas, protected natural resources would create a group of attractions, and basic activities should be their observation and sightseeing (birdwatching and game watching - photo safari, enjoying unusual sights and beauties, various researches and educations). Other contents for practicing various activities, based on mastering certain skills and special interests: hiking, bike riding, boat riding, jeep riding, train, carriage, air balloon riding, paragliding and similar., horse riding, rowing, orientation competing, nature survival, sports activities, summer eco-camps, research expeditions and similar., can be based in natural resources of a protected area, but more frequently should take place in rural environments, primarily if for practicing such activities building of larger infrastructure or occupying a larger surface is needed. Considering that small and picturesque villages with local culture Bački Monoštor, Sonta and Kupusina are located in the surroundings of SNR "Gornje Podunavlje", it represents an ideal possibility of including local population into all processes of sustainable tourism in their area for the purpose of creating profit for the members of local community. It is possible to include ethnic wealth of local communities with picturesque cultures of various nations into the integral tourism product, from architecture, to folklore, traditional customs, gastronomy, events, celebrations, artistic creations, different kinds and manners of agricultural production, using natural products, dress, old trades and making various hand-made objects. The facilities for accommodation and shopping, apart from in a symbolic volume, should be located outside the protected natural resources. We are in favor of the model of limited construction of tourism infrastructure in protected areas and the construction and usage 
of housing and other capacities in the surroundings of protected areas (messuages, accommodation in countryside households, ethno-houses, fishery houses, houses of secondary accommodation - "weekend cottages", farms, fishery huts, and similar., as well as facilities for recreational, sports and cultural-entertainment activities).

The second example could be regional destination Potisje, which would include Tisa river valley as an ecological corridor connecting a larger number of ecologically sensitive areas and protected areas - SNR: "Pašnjaci velike droplje", "Slano kopovo", "Stari Begej-Carska bara" and "Titelski breg", as well as nature parks (NP): "Stara Tisa kod Bisernog ostrva", "Jegrička" and "Kamaraš", as well as a series of areas being prepared for environmental protection, such as the river Tisa itself, attractive still waters and marshes, such as Veliki Donji Rit near Bečej and other. This destination would also include rural contents of countryside settlements and small towns, with the corresponding agricultural and free surfaces.

Tourism destinations of Vojvodina are yet to be formed, and it is to be expected that rural factors in combination with ecological and cultural will be of significant influence to their formation. According to the concentration of these elements, the following potential destinations can be distinguished: Central Danube region with Fruška Gora (SNR: "Karadjordjevo", "Begemara" and "Kovilj-Petrovaradin swamp" as well as NR "Tikvara", a spatial rural hillside of Fruška Gora with a national park in the center), Posavina ( SNR: "Zasavica" and "Obedska bara", with a river bed, spatial forest complexes and surrounding rural area), Northern Bačka (SNR: "Ludaško Lake", NP: "Palić", "Zobnatica" and "Panonija" and a landscape of extraordinary characteristics "Subotica Sands") and Southern Banat (SNR: "Deliblato Sands" and "Kraljevac", NR "Ponjavica" and a landscape of extraordinary characteristics "Vršačke mountains").

Taking into consideration the analyzed spatial-functional conditions, the basic model of the tourist product for rural destinations should be based on an efficient chain of values that includes the contents of the traditionally countryside, eco-active and ethno-tourism (Graph 2.). 
Graph 2. Model of eco-rural product

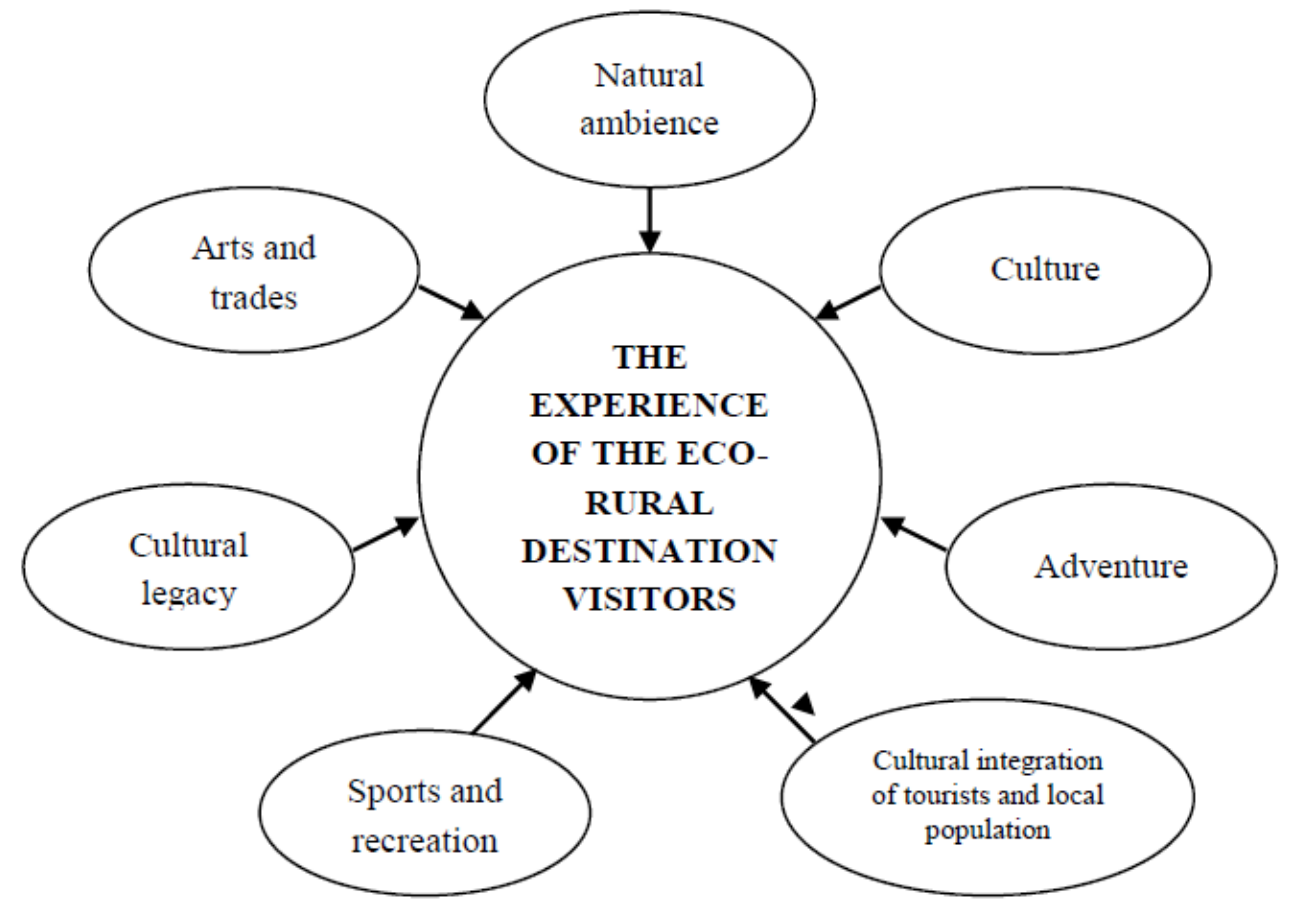

Source: Authors' research

The model of rural tourism should balance out all the components of tourism product (attractive resources, infrastructure, equipment, organization, activities and experiences). Profitable rural tourist product of Vojvodina should be at the center of the development, the integral part of which is a maximally preserved environment and cultural specificities of local community, accompanied by a constant improvement of the experience quality of the visitors.

Rural tourism in Vojodina is recognized as a revitalization factor for the villages when it comes to solving economic and demographic problems. However, rural tourism still does not have a clearly defined marketing mix of elements (product, price, promotion, and distribution), nor is its development based on the foundations of sustainable development (Njegovan et al., 2015).

\section{The areas of application of entrepreneurship in rural tourism of Vojvodina}

Entrepreneurship is a driving force of any form of economy, and its importance is particularly emphasized in tourism. Namely, in tourism, human labor is crucial in creating quality tourism offers. Rural tourism is a form of innovative economic activity. It is most frequently organized in the form of family work or small and middle-sized enterprise (SME). Examples of innovations in this area include the construction and adaptations of ecologically sustainable housing capacities, the offer of local products and organizing activities and events based on local tradition and similar. 
In Vojvodina, various tourism concepts based on entrepreneurship programs in rural communities are being developed: messuages, ethno-houses, countryside households and workshops, souvenir and old trades shop, and an offer of organically produced food.

\section{Development of tourism product in messuages}

Messuages in Vojvodina are grouped depending on the vicinity of a city:

- Sombor messuages - apart from comfortable houses, the tourism offer contains messuages without power and water pipes, equipped with old, traditional furniture

- C Čenej messuages - rich and developed agriculture of this area was historically very significant both to Čenej messuages but also for the population of Novi Sad, the city in the vicinity of which these messuages are located

- Bečej messuages - until now there was no significant attempt to active the messuages in Bečej municipality, but by forming adequate tourism product, these messuages can become tourstically active

- Subotica messuages - messuages in the northern part of Bačka were formed in the location of old medieval villages (Demirović, Njegovan, 2014).

The fate of messuages is linked to villages in many ways, although they can be also observed as a relatively independent form of habitation in the Vojvodina plain. Even today, messuages, as monuments to architectural heritage which contain a homeland type of authenticity of Vojvodinian climate, require special protection measures and a suitable care of the social community. In parallel with expert processing and placing suitable institutions under protection, we are also the witnesses of another newly created type of quasi-conservation of messuages by private caterers, degrading in its very basis.

Vanja Dragićević (2007) provides suggestions for a sustainable inclusion of messuages into the tourism offer. She lists that messuages which is decorated for tourists' needs should retain its old appearance, in order not to violate the authenticity of ambience. Messuage, as a kind of ethnographic value, is possible to also decorate as a museum, where visitors could get to know the historical story of the messuage, such way of life, various objects from everyday life of the persons inhabiting the messuage. Messuage settlements could be decorated also as ethno-parks. However, as the messuage represents not only objects, but also a way of life and activity of a Panonian peasant, the messuage should be decorated in such a way that the family - owner of the messuage, lives there during the whole year, conducts agricultural labor at the messuage property and takes in tourists, or visitors. In such a way, tourists would be able to participate in everyday life of the messuage owners, to become familiar with the tradition and folklore as a unique experience of Vojvodina plain.

Apart from that, staying in messuages should be enriched by various sports-recreational and cultural contents, which would fit in with the ambiance. As far as sports-recreational activities are concerned, horseback riding schools, nature riding should be provided, hiking and bicycle lanes which would connect the messuages should be decorated, or connect a messuage with a protected natural asset or cultural values in the surrounding area. If there any water surfaces 
located in the messuage or in the proximity of it, fishing competitions or cooking of fish stew competitions could be organized, boat riding, rowing, swimming, and similar. As far as cultural contents are concerned, we suggest organizing courses of old trades, cooking of Vojvodinian specialties, folklore nights and similar.

In the last few decades there have been several initiatives to renovate messuages for tourism purposes. Revitalization of messuages through tourism can have multiple positive effects, not only to the household, the owner of the messuage, but also to the general development of rural spaces where messuages are located, through economic, demographic, ecological, cultural, infrastructure, communal and integrative effects (Marić, 2001). Table 1. shows the number and the share of registered messuages in the area of AP Vojvodina, according to the districts.

Table 1. Territorial arrangement of messuages in Vojvodina

\begin{tabular}{|l|l|l|l|l|l|}
\hline District & Number & Share (\%) & District & Number & Share (\%) \\
\hline Northern Bačka & 9 & 21.8 & Northern Banat & 2 & 5.0 \\
\hline Western Bačka & 4 & 9.7 & Middle Banat & 1 & 2.4 \\
\hline Southern Bačka & 15 & 36.6 & South Banat & 3 & 7.4 \\
\hline Srem & 7 & 17.1 & Total & $\mathbf{4 1}$ & $\mathbf{1 0 0 . 0}$ \\
\hline
\end{tabular}

Source: Authors' calculation based on data from TOV, 2016.

Messuages (41 objects in total) comprise $27 \%$ of the objects in rural tourism in Vojvodina. They are, by large part, located in the area of Southern Bačka (15 messuages), Northern Bačka (9 messuages) and Srem district. $75.5 \%$ of all facilities of messuage type included in the rural tourism in Vojvodina are located in these districts. Only two municipalities have more than three registered/renovated messuages: Novi Sad -9 and Subotica -6 .

\section{Ethno-houses in rural tourism offer}

Ethno-houses in Vojvodina are of special value and are an important element of rural tourism offer. This element of tourism offer, apart from residential rural architecture, also includes traditional economic facilities, the structure of which depended on the type of family farm, the type of production in that farm and the socio-economic wealth of the family.

Most of these facilities, according to their origin and theme, are linked to the period of "Theresian colonization" in the second half of the $18^{\text {th }}$ century, all the way to the beginning of the $20^{\text {th }}$ century. Ethno-houses present national architecture and rural way of life of various ethnic communities. So, for example, the ethno-house in Tork (Žitište) showcases national architecture and the way of life of Romanians in Vojvodina, in Kovačica of Slovaks, in Bački Monoštor of Šokci, and in Belo Blato (Zrenjanin) of multi-ethnic community of Slovaks, Serbs, Bulgarians, Hungarians, etc.

Table 2. Territorial arrangement of ethno-houses in Vojvodina

\begin{tabular}{|l|l|l|l|l|l|}
\hline District & Number & Share (\%) & District & Number & Share (\%) \\
\hline Northern Bačka & 4 & 8.0 & Northern Banat & 6 & 12.0 \\
\hline Western Bačka & 10 & 20.0 & Middle Banat & 6 & 12.0 \\
\hline
\end{tabular}




\begin{tabular}{|l|l|l|l|l|l|}
\hline District & Number & Share (\%) & District & Number & Share (\%) \\
\hline Southern Bačka & 10 & 20.0 & South Banat & 5 & 10.0 \\
\hline Srem & 9 & 18.0 & Total & $\mathbf{5 0}$ & $\mathbf{1 0 0 . 0}$ \\
\hline
\end{tabular}

Source: Authors' calculation based on data from TOV, 2016.

More than $1 / 3$ of the facilities in rural tourism (or 50 facilities) belong precisely to this category. The largest number of ethno-houses are located in Western Bačka, Southern Bačka, and Srem districts (Table 2.). The data according to municipalities show that the largest number of registered ethno-houses is in the municipality Odžaci - 5, which is followed by Sombor, Bač, and Sremska Mitrovica with 4 facilities. It is surprising that there are almost no such facilities in Northern Bačka district, which would be included in the tourist offer despite a rich and multi-ethnic and religious diversity of this area, as well as old facilities which could be renovated.

\section{Countryside tourism households}

A countryside tourism household includes a resting house in an agricultural farm. The resting house itself, consisting of a single or several facilities, contains rooms for sleeping, a guestroom, kitchen with dining room, and it frequently has a traditional restaurant for daily guests. The food is prepared from raw materials produced at the farm, and the guests are offered other home-made products (rakija, wine, juices, honey, medicinal, cosmetic and other products). Significant attractiveness of such facilities in Vojvodina is closely related to the natural, cultural, entertainment, and recreational contents and activities which can be done in the immediate vicinity with the elements of local characteristics and heritage.

According to the Law on Tourism of RS, Article 39, a tourism organization of a local selfgovernment unit is obliged to conduct affairs of "intermediating in providing services in homecraft and countryside tourism household" and to keep a register of financial and other records. According to the same Law, Article 76, a countryside tourism household can be founded by an economic society, entrepreneur, as well as by a natural person, however, in the final case the housing capacity is limited to 30 beds.

Table 3. Territorial arrangement of countryside tourism households in Vojvodina

\begin{tabular}{|l|l|l|l|l|l|}
\hline District & Number & Share (\%) & District & Number & Share (\%) \\
\hline Northern Bačka & 1 & 3.6 & Northern Banat & 1 & 3.6 \\
\hline Western Bačka & 1 & 3.6 & Middle Banat & 0 & 0.0 \\
\hline Southern Bačka & 20 & 71.4 & South Banat & 1 & 3.6 \\
\hline Srem & 4 & 14.2 & Total & $\mathbf{2 8}$ & $\mathbf{1 0 0 . 0}$ \\
\hline
\end{tabular}

Source: Authors' calculation based on data from TOV, 2016.

It can be stated that these facilities are represented in a smaller number compared to messuages and ethno-villages in the rural-tourism offer of Vojvodina. Today, there are 28 of them in total and participate only with $19 \%$ of the total number of registered facilities in rural tourism. According to the data in Table 3., the largest part of countryside households is located in Southern Bačka district (21), and all of them almost exclusively in the Bački 
Petrovac municipality, as many as 19 . Only Srem district has more than one such household. Considering the possibilities seen by inspecting the field, as well as the fact that the registration of these households was commenced in the last 10 years, an expansion of this form of entrepreneurship in the rural tourism of Vojvodina is to be expected.

\section{Workshops and souvenir shops and shops of old trades products}

By perceiving the problem of souvenir and old trades products in the function of rural tourism in Vojvodina, we noticed insufficient presence of these products in the total tourism offer. While contacting local tourism organizations, it was noticed that even where there are already existing trading products that could be offered touristically, the manufacturers lack the marketing knowledge for the promotion and sales, as well as partnership relations with tourism operators, for the purpose of integrating these products into the wholesome offer.

Workshops and souvenirs and old trades shops comprise 1/5 of the total number of facilities in rural tourism of Vojvodina - total of 29 facilities (Table 4.).

Table 4. The arrangement of workshops and souvenir shops and ships of old trades products in Vojvodina

\begin{tabular}{|l|l|l|l|l|l|}
\hline District & Number & Share (\%) & District & Number & Share (\%) \\
\hline Northern Bačka & 0 & 0.0 & Northern Banat & 2 & 6.9 \\
\hline Western Bačka & 2 & 6.9 & Middle Banat & 2 & 6.9 \\
\hline Southern Bačka & 13 & 44.8 & South Banat & 10 & 34.5 \\
\hline Srem & 0 & 0.0 & Total & $\mathbf{2 9}$ & $\mathbf{1 0 0 . 0}$ \\
\hline
\end{tabular}

Source: Authors' calculation based on data from TOV, 2016.

Apart from the relatively small number of this type of workshops and shops, they are spatially concentrated almost exclusively in two districts - Southern Bačka and Southern Banat (79.3\%), or even narrowly, in two municipalities - Beočin (37.9\%) and Kovačica (34.5\%).

\section{Offer of food produced in the system of organic production}

Organic production includes the production of food and supplies (primary agriculture, manufacturing and distribution), but also some other products of herbal and animal origin (cloth, leather, cosmetics). According to its basic standards, it is based on the application of the agro-ecology principle. It is a legally regulated production and it includes control and certification of production and products (www.organiccentar.rs).

The basic purpose of an organic farm is self-sustainability. It is very important that a balanced relation of vegetable and animal production ensures enough food for farm animals, meaning that animal husbandry ensures organic fertilizer. On average, for 1 ha of vegetable production, 1-2 possible large livestock animals are needed. Selfsustainability is also achieved by multifunctional agriculture (diverse production) as well as by multifunctionality of agricultural household, particularly of the family type. Those are eco-farms, or Vojvodina messuages (Lazić, Malešević, www.zelenamreza.org). 
Vojvodina offers exceptional convenience for the development of agriculture within the system of organic production (Pejanović, Njegovan, 2011). Worldwide, there is trend of including these products into the gastronomic offer of rural tourism. The offer of food produced in such a way would contribute to improving the quality of gastronomic offer within the tourism offer of Vojvodina, and it would also contribute to an increase of this production in Vojvodina.

In Vojvodina, there is no unified basis of organic food manufacturers, but certain areas have become recognized by organic production. Placing the organically produced products into the tourism offer would ensure profitability and sustainability of organic production and authenticity of tourism offer. Some settlements that have the potential of becoming the destinations of bio-rural tourism are: Selenča - organic juices, farmer crops, Japanese apples (kaki), Sombor - a wide assortment of raw, vegan, biological and organic food products, Stajievo - organic cereal, Hajdukovo - cold pressed edible herbal oils, oil seeds butter, Pivnice and Temerin - organic vegetables, Čurug - organic milk and meat, Stari Ledinci - organic grapes and wine, Novi Sad - cold pressed edible herbal oils, homemade soap and cosmetics. NGO Green Network of Vojvodina (Novi Sad) plays an important role in the development of organic agriculture - arranges educations, gathers certified manufacturers, promotes and places organic products in the "My messuage" market and a specialized shop. Vojvodina cluster of organic production is also formed in Novi Sad (www.organiccentar.rs).

For the purpose of developing bio-rural tourism in the area of Vojvodina, it is necessary to ensure financial means for subventions from the provincial budget, which would also include supporting the development of organic agriculture in an agricultural household, but also supporting the development of rural tourism in that household (Radović et al., 2011).

\section{Conclusion}

As far as tourism destinations of rural character are concerned, tourism is the main generator of entrepreneurship development in activities directly or indirectly contributing to product formation and services for the visitors (accommodation in facilities in a family farm, gastronomic offer, recreational activities, festivals and events, trades and folk art). The most important effects of rural tourism can be seen in the development of entrepreneurship at a destination, and the influence on infrastructure construction. A direct influence of rural tourism can be seen in increased production and ensuring a safe placement of agricultural products, increased employment rate of local population, and the growth of their wages. Local rural system plays a very important role in the process of rural tourism development. Efficient management of rural tourism development is not possible without cooperation and partnerships of all stakeholders. The development of rural tourism should be based on effective investment into tourism offer by creating entrepreneurial projects that are in accordance with modern market trends.

Vojvodina has significant natural and social resources that can contribute to the development of entrepreneurship in rural tourism. In order for a continued development of entrepreneurship, it is necessary to actively include social, political and other institutions and individuals to create pre-conditions and facilitate initiating entrepreneurial activities. 
It is necessary to increase the efforts to renovate numerous localities and facilities, which can improve the pride of local community towards their local area, customs and heritage, and can encourage individuals to start or expand entrepreneurial projects in rural tourism. The development of entrepreneurship as far as rural tourism in Vojvodina is concerned must be based on the principles of sustainable development. If a destination decides that rural tourism is its chosen direction of development, it must carefully plan and manage that development, which will not only satisfy the needs of tourists but should also ensure sustainable development of local community.

\section{References}

1. Andrić, N., Tomić, D., Tomić, G. (2010): Status and Perspectives of Development of Rural Tourism in the Autonomous Province of Vojvodina. 118th EAAE Seminar- Rural development: governance, policy design and delivery, Ljubljana, Slovenija, pp. 611621.

2. Bogdanov, N. (2007): Mala ruralna domaćinstva u Srbiji i nepoljoprivredna ekonomija. UNDP, Beograd, Srbija.

3. Butler, R.W. (1998): Rural recreation and tourism, in B. Ilbery (ed) - The geography of rural change, pp. 211-32, Addison Wesley Longman, Harlow, UK.

4. Čikić, J., Petrović, M., Đurđev, B. (2015): Difusion of knowledge and rural tourism development-Example of Vojvodina. Economics of Agriculture, Vol. 62, No. 1, pp. 123-136, Institute of Agricultural economics, Belgrade, Serbia.

5. Demirović, D., Njegovan, Z. (2014): Tourist satisfaction with perceived values on traditional farms in AP Vojvodina. U: D. Cvijanović (ed.), Conference - Sustainable agriculture and rural development in terms of the Republic of Serbia strategic goals realization within the Danube region, Belgrade, Serbia, pp. 648-664.

6. Demonja, D., Baćac, R. (2012): Contribution to the Development of Rural Tourism in Croatia: Proposed Steps for Successful Business. Turizam, Vol. 16, No. 4, pp. 134-151, Institut za turizam, Zagreb, Hrvatska.

7. Dragićević, V. (2007): Turizam kao faktor revitalizacije salaša-primer Cvetnog $i$ Majkinog salaša na Paliću. Zborbik radova Geografskog instituta „Jovan Cvijić“, 57 , pp. 223-231, SANU, Beograd, Srbija.

8. Đuričić, B. Đ. (2011): Uticaj turizma na razvoj agrarne proizvodnje u Zlatiborskom okrugu. Naučna konferencija sa međunarodnim učešćem - Agrobiz 2011, Novi Pazar, Srbija, pp. 115-122.

9. Fesenmaier, J., Fesenmaier, D., Van Es, J. C. (1995): The nature of Tourism Jobs in Illinois: Draft Report, University of Ilinois, Laboratory for Community and Economic Development, Ilinois, USA.

10. Gannon, A. (1994): Rural tourism as a factor in rural community economic development for economies in transition. Journal of Sustainable Tourism, pp. 51-60, Taylor \& Francis Online. 
11. Garrod, B., Wornell, R.,Youell, R. (2006): Re-conceptualising rural resources as countryside capital: The case of rural tourism. Journal of Rural Studies, Vol. 22, No. 1, pp. 117-28. Institute of Rural Sciences, University of Wales Aberystwyth, Aberystwyth, UK.

12. Greffe, X. (1994): Is rural tourism a lever for economic and social development? Journal of Sustasinable tourism, Vol. 2, No. 1-2, 22-40, Taylor \& Francis Online.

13. Heijman, W., Hagelaar, G., Heide, M.v.d., (2007): Rural resilience as a new development concept, EAAE seminar Serbian Association of Agricultural Economists, Novi Sad, Serbia.

14. Jegdić, V. (2010): Model razvoja ekoturizma u Vojvodini. Ekonomski horizonti, Vol. 12, No. 1, 63-78, Kragijevac, Srbija.

15. Jegdić, V. (2011). Turizam i održivi razvoj. Fakultet za sport i turizam, Novi Sad, Srbija.

16. Kieselbach, S. R., Long, P. T. (1990): Tourism and the rural revitalization movement. Parks and Recreation, 25(3), pp. 62-66, Sagamore Publishing, Arlington, USA.

17. Krajnović, A., Čičin-Šain, D., Predovan, M. (2011): Strateško upravljanje razvojem ruralnog turizma - problemi i smjernice. Oeconomica Jadertina, pp. 30-45, Sveučilište u Zadru, Odjel za ekonomiju, Zadar, Hrvatska.

18. Lane, B. (1994): What is rural tourism?, Journal of Sustainable Tourism, Vol. 2, No. 1-2, pp. 7-21, Channel View Publications, Clevedon, United Kingdom.

19. Lane, B. (1999). What is Rural Tourism? Its Role in Sustainable Rural Development, Paper presented at Nordisk Bygdeturism Nätverk Conference, Kongsvinger, Norvay, available at: http://www.bygdeturism.com/kongs1.pdf

20. Lazić, B., Malešević, M: Organska poljoprivreda, Institut za ratarstvo i povrtarstvo, Novi Sad, Srbija, available at: http://www.zelenamreza.org/home/multifinkcionalnapoljoprivreda/odrziva-poljoprivreda/vise-o-odrzivoj-poljoprivredi-i-korisne-adrese/ organska-poljoprivreda-da.html

21. Marić, R. (2001): Turistička delatnost - bitan faktor prosperitetnijeg razvoja ruralnih područja, Prvi forum - Ruralni turizam i održivi razvoj Balkana. Zbornik radova, Kragujevac, Srbija, pp. 120-140.

22. McAreavey, R., McDonagh, J. (2010): Sustainable Rural Tourism: Lesson for Rural Development. Sociologia Ruralis, Vol. 51, No. 2, pp. 175-94, Queens University Belfast, Belfast, UK.

23. Njegovan, Z., Demirović, D., Radović, G. (2015): Upravljanje održivim razvojem ruralnog turizma u Vojvodini. Škola biznisa, No. 1, pp. 68-79, Visoka poslovna škola strukovnih studija, Novi Sad, Srbija.

24. Novelli, M. (2005): Niche Tourism. Contemporary Issues, Trends and Cases, Elsevier Butterworth-Heinemann, Burlington, MA, USA.

25. OECD, (1994): Stvaranje ruralnih indikatora za uokvirivanje teritorijalnih politika, Paris. 
26. Page, S.J., Getz, D. (1997): The business of rural tourism: International perspectives. International Thomson Business Press, London, UK.

27. Pejanović, R., Njegovan, Z. (2011): Principi ekonomije i agrarne politike. Poljoprivredni fakultet, Novi Sad, Srbija.

28. Petrou, A., Pantziou, E.F., Dimara, E., Skuras D. (2007): Resources and activities complementarities: the role of business networks in the provision of integrated rural tourism. Tourism Geographies, Vol. 9, No. 4, pp. 421-40, Taylor \& Francis Online.

29. Puzović, S., Panjković, B. (2015): Upravljanje prirodnom baštinom u Vojvodini. Pokrajinski zavod za zaštitu prirode, Novi Sad, Srbija.

30. Radović, G., Pejanović, R., Glavaš-Trbić, D. (2011): Problem finansiranja proizvodnje zdravstveno bezbedne hrane kao faktora razvoja ruralnog turizma u AP Vojvodini. U: M. Krajinović (ur.), 22nd International Symposium Food safety production, Proceedings, Poljoprivredni fakultet, Trebinje, BiH, pp. 241-242.

31. Rikalović, G., Stojanović Ž., Zorka Z. (2012): Novi obrazac privrednog razvoja i zapošljavanja - model kreativne ruralne industrijalizacije. Zbornik Matice srpske za društvene nauke No. 141, pp. 565-82, Matica srpska, Novi Sad, Srbija.

32. Rural Sociological Society and the National Coalition for Rural Entrepreneurship. (2006, January). Tourism and Amenity-based Development in Rural Communities. Issue Brief: Challenges for Rural America in the Twenty-first Century, available at: http://www.ruralsociology.org/briefs/briefs3.pdf

33. Saxena, G., Clark, G., Oliver, T., Ilbery, B. (2007): Conceptualising integrated rural tourism. Tourism Geographies, Vol. 9, No. 4, pp. 347-70, Taylor \& Francis Online.

34. Sharpley, R., Jepson, D. (2011): Rural tourism: A spiritual experience? Annals of Tourism Research, Vol. 38, No. 1, pp. 52-71. Elsevier B.V.

35. Shouten, M., Heide, M. v.d., Heijman, W. (2009): Resilience of social-ecological sistems in European rural areas: Theory and prospects. Paper prepared for presentation at the 113th EAAE seminar: The role of knowledge, innovation and human capital in multifunctional agriculture and territorial rural development, Institute of Agricultural Economics, Belgrade, Serbia, pp. 117-130.

36. Shtaltovna, A. (2007): Role of Governance in the Diversification of Rural Economy, Analysis of two Ukrainian Cases, M.Sc. thesis, Ghent University of Belgium, Ghent, Belgium.

37. Silva, L., Leal, J. (2015): Rural tourism and national identity building in contemporary Europe: Evidence from Portugal. Journal of Rural Studies, Vol. 38, pp. 109-19, Elsevier.

38. Škrbić, I., Jegdić, V. Milošević, S., Tomka, D. (2015). Development of Sremski Karlovci wine tourism and integration in the regional tourism offer. Economics of agriculture, LXII(1/2015), pp. 229-244. Institute of Agricultural economics, Belgrade, Serbia.

39. Todorović M., Štetić, S. (2009): Ruralni turizam. Univerzitet u Beogradu, Geografski 
fakultet, Beograd, Srbija.

40. Vidić, N. (2012): Razvoj turizma ruralnih prostora. U D. Tomka, V. Jegdić (ur.)

Turizam i lokalni razvoj, naučna monografija, pp. 129-134. Fakultet za sport i turizam, Novi Sad, Srbija.

41. Zakon o turizmu, Službeni glasnik Republike Srbije, no. 84/2015.

42. http://www.organiccentar.rs/baza-proizvodaca/

43. http://www.travinfoindia.com/rural_india_travel.html

\title{
MODELI RAZVOJA PREDUZETNIŠTVA U DESTINACIJAMA RURALNOG TURIZMA U VOJVODINI
}

\author{
Vaso Jegdič́, Iva Škrbičc, Srđan Miloševič ${ }^{7}$
}

Rezime

Predmet istraživanja u ovom radu predstavlja razvoj i primena modela preduzetništva $u$ destinacijama ruralnog turizma. Cilj rada je identifikovati ključne oblike preduzetništva u destinacijama ruralnog turizma u Vojvodini. Primenjen je opšti analitičko-sintetički metod istraživanja, u rasponu od bibliografsko-spekulativnog, do empirijskog pristupa.

Utvrđeno je da salaši, sela kao turistički proizvodi, etno-kuće i seoska domaćinstva koja pružaju usluge smeštaja $i$ ishrane, eko-aktivni turizam, turistička ponuda hrane i pića proizvedenih u sistemu organske proizvodnje, kao i tradicionalne ruralne manifestacije mogu da budu osnova proizvoda ruralnog turizma Vojvodine. Razvoj ruralnog turizma treba da se zasniva na efektivnom investiranju u turističku ponudu kroz preduzetničke projekte koji su u skladu sa savremenim trendovima na strani tražnje. Investiranje u turističku ponudu u destinacijama ruralnog turizma uticalo bi na rast prihoda od ruralnog turizma, a samim tim i na ekonomski razvoj tih oblasti.

Ključne reči: ruralni turizam, ruralna destinacija, preduzetništvo u ruralnom turizmu, Vojvodina.

5 Vanredni profesor, dr Vaso Jegdić, Univerzitet Edukons, Fakultet za sport i turizam, Radnička Ulica br. 30a, 21000 Novi Sad, Telefon: +381 635506 38, E-mail: vaso.jegdic@tims.edu.rs

6 Docent, dr Iva Škrbić, Univerzitet Edukons, Fakultet za sport i turizam, Radnička Ulica br. 30a, 21000 Novi Sad, Telefon: +381642014 738, E-mail: iva@tims.edu.rs

7 Docent, dr Srđan Milošević, Univerzitet Edukons, Fakultet za sport i turizam, Radnička Ulica br. 30a, 21000 Novi Sad, Telefon: +381 641800 431, E-mail: $\underline{\text { srdjan.milosevic@tims.edu.rs }}$

EP 2017 (64) 1 (221-237) 
ECONOMICS OF

AGRICULTURE

\section{CONTENT}

1. Željko Anđelković, Aleksandra Dragin, Sanja Božić, Kristina Košić

EMOTIONAL EXHAUSTION AND JOB SATISFACTION OF TOUR GUIDES IN RURAL AREAS . . . . . . . . . . . . . . 11

2. Sanja Đukić, Danica Glavaš-Trbić, Nikola Banjac

MANAGEMENT PROBLEMS OF RURAL DEVELOPMENT IN FRUŠKA GORA . . . . . . . . . . . . . . . . . . . . 27

3. Ivana Ilić, Bojan Krstić, Sonja Jovanović

ENVIRONMENTAL PERFORMANCES OF AGRICULTURE IN THE EUROPEAN UNION COUNTRIES . . . . . . . . . . . . . 41

4. Nataša Kljajić, Jonel Subić, Zorica Sredojević

PROFITABILITY OF RASPBERRY PRODUCTION

ON HOLDINGS IN THE TERRITORY OF ARILJE. . . . . . . . . . . 57

5. Aleksandar Maksimović, Zoran Grgić, Ferhat Ćejvanović

MULTI-ATTRIBUTE ANALYSIS OF ORCHARD ACCORDING

TO THE INTEGRATED PRODUCTION CONCEPT . . . . . . . . . . 69

6. Ozrislava Milinković, Branislav Jakić, Slobodan Vuksanović,

Dragana Macura, Milica Šelmić

MULTI- CRITERIA DECISION BASED APPROACH

TO SELECTING THE TYPE OF INDUSTRIAL HALLS

USED IN FOOD INDUSTRY $\ldots \ldots \ldots \ldots$. . . . . . . . . . 81

7. Gordana Nikić, Ljubiša Stamatović, Azra Sućeska

EMOTIONAL COMPETENCIES AND PERSONALITY

TRAITS OF MANAGERS IN MODERN AGROBUSINESS. . . . . . . .97

8. Vladimir Obradović, Nemanja Karapavlović

FINANCIAL REPORTING OF COMPREHENSIVE INCOME

IN THE FOOD AND BEVERAGE SECTOR

IN THE REPUBLIC OF SERBIA . . . . . . . . . . . . . . 113 
9. Aleksandar Ostojić, Nebojša Savić, Željko Vaško

CONSUMER ATTITUDES

ON BUYING FISH IN BANJA LUKA . . . . . . . . . . . . . . . 129

10. Radivoj Prodanović, Boris Kuzman, David Jovović, Lazar Ozegović

MARKET AND TRADE OF ORGANIC FRUITS IN SERBIA $\ldots . . .141$

11. Predrag Vukadinović, Aleksandar Damnjanović, Ljiljana Dimitrijević

ANALYSIS OF THE SALES AND INCOMES BETWEEN

DIFFERENT CATEGORIES OF AGRICULTURAL PRODUCTS . . . 157

12. Jugoslav Aničić, Svetlana Vukotić, Goran Maksimović

THE POSSIBILITIES AND LIMITATIONS

OF ENTREPRENEURSHIP DEVELOPMENT

IN AGRICULTURE IN SERBIA . . . . . . . . . . . . . . 171

13. Željko Bjelajac, Marijana Dukić - Mijatović, Joko Dragojlović

FOOD SAFETY AS ONE OF THE MAIN SAFETY $P$

REOCCUPATIONS OF A MODERN MAN . . . . . . . . . . . . . 191

14. Milan Bradić, Ljiljana Kosar, Lukrecija Djeri, Svetlana Vukosav, Vuk Garača

ECO-LABELLING OF ACCOMMODATION FACILITIES

AND ITS PERCEPTION BY RURAL TOURISTS:

CASE STUDY OF VOJVODINA . . . . . . . . . . . . . . 205

15. Vaso Jegdić, Iva Škrbić, Srđan Milošević

MODELS OF ENTREPRENURSHIP DEVELOPMENT

IN RURAL TOURISM DESTINATIONS IN VOJVODINA . . . . . . . 221

16. Duško Kuzović

MUSEUM OF VERNACULAR ARCHITECTURE OF WESTERN SERBIA

- Representative curtilages of the area surrounding middle

course of the river Drina and Podgorina . . . . . . . . . . . 239

17. Branko Mihailović, Zoran Simonović, Nikola Ćurčić

AGRICULTURAL RESOURCES AND DEVELOPMENT

PRIORITIES OF THE MUNICIPALITY OF STARA PAZOVA. . . . . 259

18. Radmilo Nikolić, Aleksandra Fedajev, Vidoje Stefanović, Silvana Ilić

THE AGRICULTURE SECTOR IN WESTERN BALKANS

- SOME CHARACTERISTICS OF DEVELOPMENT. . . . . . . . . . 275

19. Vladimir Njegomir, Rajko Tepavac, Nenad Ivanišević

ALTERNATIVE SOURCES OF FINANCING

ENTREPRENEURIAL UNDERTAKINGS IN AGRICULTURE . . . 295

Economics of Agriculture, Year 64, No. 1 (1-404) 2017, Belgrade 
20. Daniela Nuševa, Kristina Mijić, Dejan Jakšić

THE PERFORMANCES OF COFFEE PROCESSORS

AND COFFEE MARKET IN THE REPUBLIC OF SERBIA . . . . . . 307

21. Svetlana Roljević Nikolić, Predrag Vuković, Biljana Grujić

MEASURES TO SUPPORT THE DEVELOPMENT OF ORGANIC

FARMING IN THE EU AND SERBIA . . . . . . . . . . . . 323

22. ŽeljkoVojinović, Vera Zelenović, DragoCvijanović

PROGRAM OF STATE SUPPORT

TO AGRICULTURAL CREDITING. . . . . . . . . . . . . . . . 339

23. Nikola Vuksanović, Dragan Tešanović, Bojana Kalenjuk,

Milijanko Portić, Marija Knežević

SOCIO-DEMOGRAPHIC CHARACTERISTICS

AS DETERMINANTS OF DIFFERENCES

IN PERCEPTION OF LOCAL GASTRONOMY . . . . . . . . . . . . 359 